\title{
Job, career or calling: a qualitative exploration of the meaning of work among Brazilian undergraduate architecture students
}

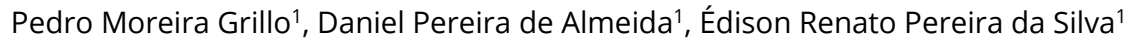 \\ ${ }^{1}$ Universidade Federal do Rio de Janeiro (UFRJ), Production Engineering Program, Rio de Janeiro, RJ, Brazil
}

How to cite: Grillo, P.M., Almeida, D.P. and Silva, É.R.P. (2021),“Job, career or calling: a qualitative exploration of the meaning of work among Brazilian undergraduate architecture students", Brazilian Journal of Operations \& Production Management, Vol. 18, No. 1, e20211100. https://doi.org/10.14488/BJOPM.2021.002

\section{ABSTRACT}

Goal: To explore the relationship between different motivations and expectations and attributed meanings of work: as a job, career or calling.

Design / Methodology / Approach: A survey with 82 undergraduate architecture and urbanism students was carried out, using with two seminal meaning of work questionnaires. Results were analyzed qualitatively.

Results: (i) It is viable to analyze work as a job, career or calling; (ii) most of the interviewees (90\%) faces work as something more than a job; (iii) It was shown that each subgroup has different motivations; (iv) It was also demonstrated that this subject is perceived as of great relevance for young people.

Limitations of the investigation: Samples (size and subgroup) and qualitative analyses of the results were the major limitations. Therefore, bigger samples and different interviewees could increase validity of results.

Practical implications: For organizations, the human resources department could add strategies about work perception on the employee hiring process. For individuals, the awareness of multiple meanings of work could be helpful in changing personal insights that influence careers and wellness.

Originality / Value: The paper brings unprecedent approach and has some contributions to the field, such as: questionnaires translations and their use combined for the first time, besides the sample choice, which has also never been addressed before with this approach.

Keywords: Meaning of Work; Work Orientation; Calling.

\section{INTRODUCTION}

Working constitutes more than a third of the lives of most adult humans. It is vitally important, especially in the context of the western world Wrzesniewski, et al. (1997). Work is a central theme and has also undergone changes, both in its form and in its content, bringing the need for increasingly studying the meaning of work for the future (Gratton, 2010). Morse and Weiss (1955) is one of the pioneering studies on the meaning of work in the United States. Known as "lottery studies", it investigated the meaning of work with one fundamental question: "Would you continue to work if you won the lottery?". Over $80 \%$ of the responses were positive. The meaning of work has been discussed for centuries with religious and philosophical worldviews. In the 1980's, the field had the most relevant research, which

Financial support: None.

Conflict of interest: The authors have no conflict of interest to declare.

Corresponding author: grillo.pedro@gmail.com

Received: 12 Oct 2020

Approved: 14 Oct 2020

Editor: Osvaldo L. G. Quelhas and Julio Vieira Neto. 
ushered in an era of increased academic studies regarding the theme (such as MOW International Research Team, 1987).

The meaning or work has been increasingly discussed since the 80 's, and in the last 15 years the volume of publications on this subject has been intensified. However, scholars agree that more studies are needed. According to Rosso et al. (2010) the literature is still in its adolescence, searching for a coherent identity between the theoretical lines.

Regarding the discussion about the importance of a clear definition of terms, Morin et al (2007, p.47) states that "the analysis of the work of the senses is not a unanimous issue" Goulart (2009, p.47) says that "[...] the meaning of work houses several possibilities for analysis and understanding". Ardichvili and Kuchinke (2009, p.157) point out that theArdichvili and Kuchinke (2009, p.157) point out that the "(inicio aspas)review of related definitions and conceptual frameworks suggests that the authors use the terms meaning of work (formatar itálico) and meanings of working (formatar itálico) interchangeably". Bendassolli et al (2015) seeks to understand the terminology of Brazilian publications and call attention to the issue of translation, making a significant theoretical contribution by distinguishing some used terms. The authors chose to use the term "conceptual imprecision" to refer to the various existing currents and terminologies.

According to Geldenhuys et al (2014) there has been a continuous growth on research about meaningful and significant work (Dik and Duffy, 2009; Hult, 2005; Schaufeli and Bakker, 2004). King and Napa (1998) suggest that meaningful work and significance is a more desired theme that happiness and wealth, and young workers "incessantly talk about meaning", citing the lack of meaning as a key factor for turnover (Lancaster and Stillman, 2011, p. 86).

Wrzesniewski et al. (1997) states that most people see the work as a job, a career or a calling. Over the years, several authors associated the meaning of work as a calling meaningful work - with positive results, both for individuals and for organizations, which makes the topic relevant (Berg et al., 2010; Bunderson and Thompson, 2009; Elangovan et al., 2010; Hackman and Oldham, 1980; Kahn, 2007; Locke and Taylor, 1991; May et al., 2004; Pratt et al., 2006; Roberson, 1990; Rosso et al., 2010; Spreitzer, 1996; Wrzesniewski and Dutton, 2001; Wrzesniewski et al., 1997; Wrzesniewski, 2003).

Despite all the discussion and studies across different countries, there are gaps that this paper aims to contribute: (i) The research on work orientation based on Wrzesniewski et al. (1997) was never tested in Brazilian context; (ii) The questionnaires used by Wrzesniewski et al. (1997) and the seminal work of MOW (MOW International Research Team, 1987) were never applied combined. The replication study presented aims to contribute to a coherent identity and maturity of the field.

This paper aims to (i) show that the work can be seen as a job, career or calling, and the approach used (unprecedented in Brazil) proved consistent; (ii) explain the results and discuss the work seen as more than just a job as beneficial; (iii) explain the relationship between meaning of the work with professional environment motivations; (iv) explain the perceived relevance of the theme for the respondents.

\section{THEORETICAL FRAMEWORK}

The term 'meaning of work' became institutionalized in the academic literature, psychology of work in particular, with the publication of a research conducted by an international research team, known as Meaning of working team (MOW International Research Team, 1987). This research is a milestone, as it is the most extensive survey on this subject, involving data collection in eight countries, with a total sample of 8,749 people (Bendassolli, 2009). According to Bendassolli and Borges-Andrade (2011), the meaning of work has been a research theme for several decades and for various academic disciplines (Borges, 1997; Brief et al., 1995; Brief and Nord, 1990; Drenth, 1991; Fox, 1980; MOW International Research Team, 1987; Pryor and Davies, 1989; Ruiz-Quintanilla, 1991; Quintanilla and England, 1996; Weiss and Kahn, 1961). Rosso et al. (2010) is another significant milestone, being the wider literature review regarding the subject. 
Bendassolli and Borges-Andrade (2015) succinctly describes theoretical streams in the field, dividing it in two main categories: "meaning of work" and "meaningfulness of work". This distinction is considered plausible for reasons already mentioned by other authors, such as Lips-Wiersma and Morris (2009), Pratt et al. (2003), Rosso et al. (2010).

Meaning of work is the most traditional in literature and tends to emphasize the cognitive dimensions of meaning (Rosso et al., 2010). Bendassolli and Borges-Andrade (2015) describes that this category brings together studies aiming to determine what the meaning of work is that is, the cognitive representations and maps that organize a person's work experience. According to the authors, at least six major research topics were inspired by this concept: (i) centrality of work, (ii) work orientation, (iii) beliefs and values related to work, (iv) causes and consequences of the prolonged absence of work, $(\mathrm{v})$ work meanings across different cultures and (vi) social representations of work

Meaningfulness of work is related to the psychological mechanisms that allow individuals to consider their work as having the potential to be meaningful (Rosso et al., 2010). It focuses on what characteristics must be present at work - or person - so it can be possible to perceive meaning at it, and the psychological mechanisms involved in experiencing meaning at work.

In short, both categories reflect a diversity of perspectives. The fact that they were discussed separately does not mean that they are independent of each other, although there may be differences between them. Some authors have reported both or admit the influence of both in their studies - for example, Morin $(1996,1997)$.

Based on these discussions, the definition used for this study is that the meaning of work is what work represents for the person in general. It can be seen as a job, a career or a calling (Table 1) (Wrzesniewski et al., 1997). According Rosso et al. (2010), this theoretical framework refers to individual's beliefs related to work in general, not one in particular job. This line of research is called in the literature of "work orientation".

Table 1. Conceptual definition

\begin{tabular}{ccc}
\hline Job & Career & Calling \\
\hline $\begin{array}{c}\text { Focused on extrinsic aspects and } \\
\text { material benefits. Does not seek any } \\
\text { kind of accomplishment and search } \\
\text { at work a way to carry it out. }\end{array}$ & $\begin{array}{c}\text { Invest at work and are } \\
\text { interested in it, focusing on } \\
\text { professional learning and } \\
\text { growth. Status is the main } \\
\text { benefit focused. }\end{array}$ & $\begin{array}{c}\text { See work as an extension of life, } \\
\text { seeking more than material } \\
\text { benefits and status, a personal } \\
\text { achievement and realization. }\end{array}$ \\
\hline
\end{tabular}

Source: Adapted from Wrzesniewski et al. (1997)

\section{METHOD}

This study is empirical, using two seminal questionnaires (MOW International Research Team, 1987 and Wrzesniewski et al., 1997) with the purpose of replication, aiming an internal consistency. The questionnaires were applied to 82 people $(n=82)$ in person and online, with the help of university professors. The structured data collected was analyzed qualitatively.

The approach used to find and filter the conceptual framework followed the provisions of Silva and Proença Júnior (2013), with a Systematic Literature Mapping. A total of 2325 works were analyzed and filtered in order to understand the field and its theoretical lines (Grillo, 2019).

To describe the meaning of work using this conceptual basis, two questionnaires were used together, The Work-life questionnaire (WLQ) based on Wrzesniewski et al. (1997) and the classic questions of the meaning of MOW's work (MOW International Research Team,1987). Besides the view of work as a job, career or calling, questions were taken from the classic field study, the Meaning of Working International Research Team (MOW). Due to its relevance and history, the MOW (MOW International Research Team, 1987) questionnaire was used to complement the characteristics of the meaning of work, aiming to analyze whether the view of work as Job, Career or Calling influences the meaning of work according to the classical construct. 
A total of 82 final-year Architecture and Urbanism students from three universities of Niterói-RJ were interviewed. All students were doing their final project, the last requisite to graduate. Niterói had, in 2017, 974 people enrolled in Architecture and Urbanism courses, with 56 graduates (Instituto Nacional de Estudos e Pesquisas Educacionais Anísio Teixeira, 2019). The number of students analyzed corresponds to about 10\% of total enrollment in 2017 and responds consistently to the numbers graduating in the same year, representing the share of young architects and city planners entering the labor market that year.

The reason for choosing this group (architecture students about to graduate) is that (i) they are about to graduate and enter job market, most of them already have some working experience, and a purposeful sample allows for understanding a phenomenon in depth; (ii) since there are no studies in using this questionnaire in Brazil, segmenting and performing it with new audiences is interesting for scholars; (iii) feasibility of the research.

Data analysis was done qualitatively upon the structured data, looking for the average meaningful patterns. The choice of the qualitative approach was because it was more important to understand the phenomenon than to statistically prove a theory.

\section{RESULTS}

\section{Profile of respondents}

Regarding the geographic distribution of respondents, half of the people live in Niterói, where the University is located, $17 \%$ live in Rio de Janeiro city, $12 \%$ in São Gonçalo, $6 \%$ in Maricá, 5\% in Itaboraí, 2\% in São João de Meriti and 6\% in other cities. Regarding gender, 62,2\% are women and $37,8 \%$, men. Most of respondents $(74,4 \%)$ was aged between 18 and 27 years old (Figure 1).

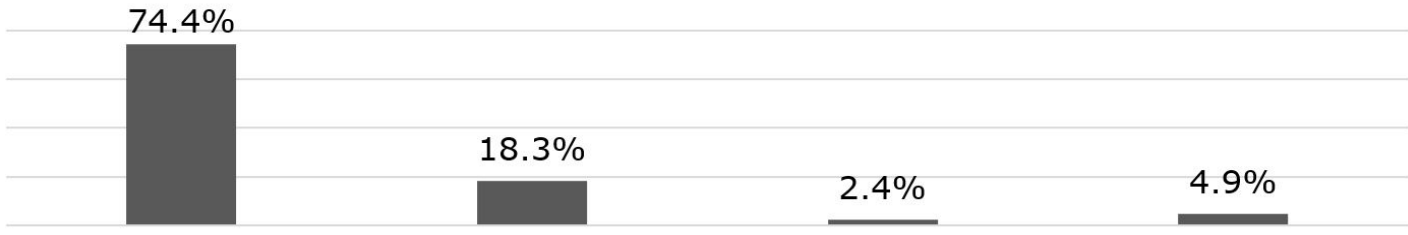

Between 18 and 27 Between 28 and 37 Between 38 and 47 Beyond 47 years old years old years old years old

Figure 1. Age of respondents Source: Authors

In terms of the economic profile and family income, there $96,4 \%$ said having more than minimum wage as income, with quite a uniform distribution for groups beyond the minimum wage (Figure 2).

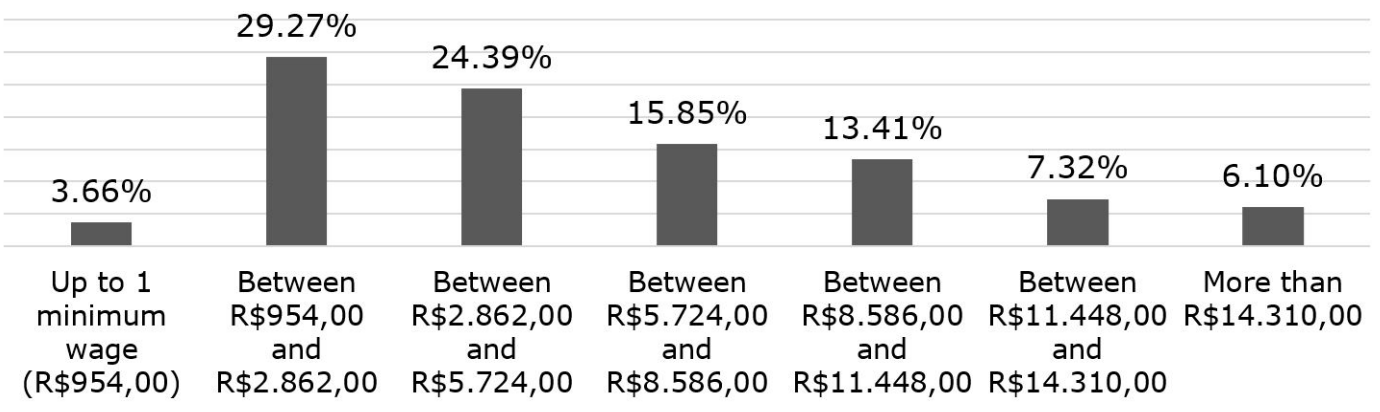

Figure 2. Family income profile Source: Authors 
This demographic analysis demonstrated the majority as a diverse, young, female and little homogeneous group, concerning income and residence. The results are consistent with the studied sample choice.

\section{Meaning of work as a Job, career or calling}

The three group segmentation (job, career or calling) followed the methodology used by Wrzesniewski, et al. (1997), in which each person answers three questions, each corresponding to the profile (job, career or calling), without knowing the classification, and must rank from 0 to 3 how much they identify with the sentence. Some participants (28\%) misunderstood the instructions and rated equally in first place two or more questions, and these answers were not used in the result. This misunderstanding was also identified in Wrzesniewski et al. (1997) research with similar percentage.

According to the answers, most of the people see work as career (61\%), 29\% understand it as calling and only (10\%), a minority, see it as a job (Figure 3 ).

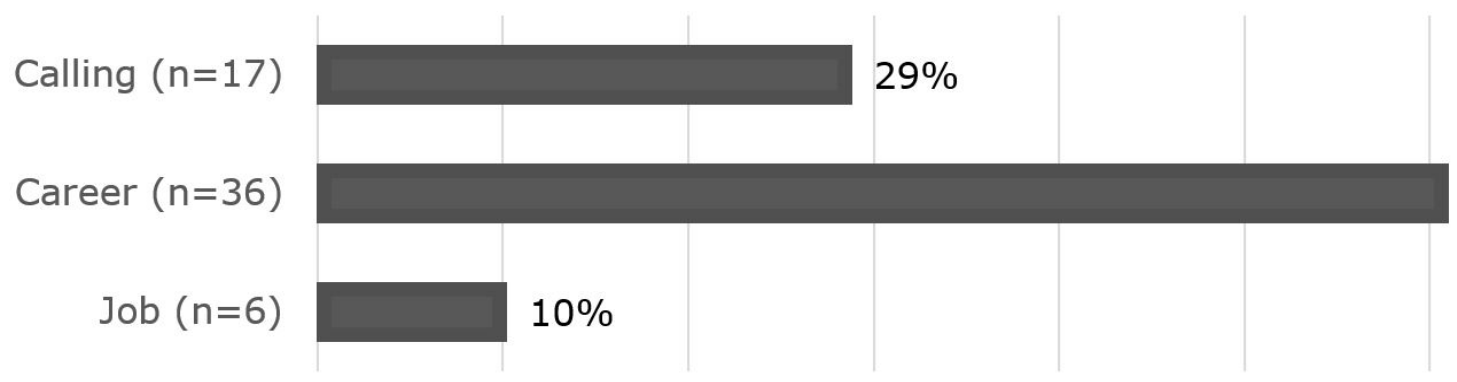

Figure 3. Meaning of work among subgroups

Source: Authors

The average of the replies and the standard deviation (in brackets) are shown in Chart 1 and Figure 4. The results show internal consistency facing to what was proposed by Wrzesniewski et al. (1997).

Chart 1 - Average answers about the meaning of work by subgroup and standard deviation

\begin{tabular}{cccc}
\hline Rating by group & Job $(\mathbf{n}=\mathbf{6})$ & Career $(\mathbf{n}=\mathbf{3 6})$ & Calling (n=17) \\
\hline Job & $2,2(0,9)$ & $1,0(0,6)$ & $0,3(0,4)$ \\
\hline Career & $0,5(0,6)$ & $2,6(1,2)$ & $0,8(0,7)$ \\
\hline Calling & $0,2(0,5)$ & $0,5(0,8)$ & $2,2(1,1)$ \\
\hline
\end{tabular}

Source: Authors

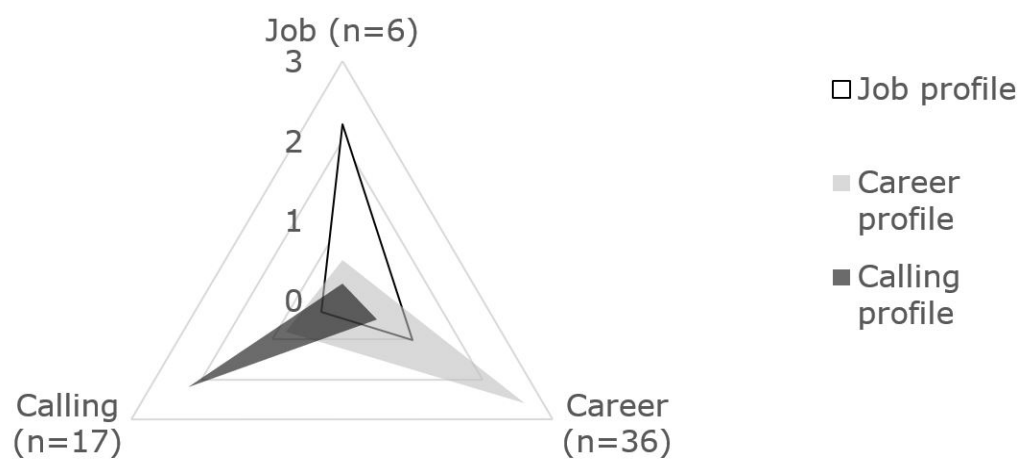

Figure 4 - Profiles of answers about the meaning of work by subgroup Source: Authors 
Some patterns appear when analysing the subgroups (Chart 2). The majority of people with higher income sees work as a job, comparing to the other. This same subgroup, together with private school students, had the lowest percent of those who see work as calling.

Chart 2 - Meaning of work and subgroups analysis

\begin{tabular}{cccc}
\hline & Job $(\mathbf{n}=\mathbf{6})$ & Career $(\mathbf{n = 3 6 )}$ & Calling $(\mathbf{n = 1 7})$ \\
\hline General $(\mathrm{n}=59)$ & $10 \%$ & $61 \%$ & $29 \%$ \\
\hline Age (younger than 30 years old) $(\mathrm{n}=52)$ & $10 \%$ & $62 \%$ & $29 \%$ \\
\hline Age (older than 30 years old) $(\mathrm{n}=7)$ & $14 \%$ & $57 \%$ & $29 \%$ \\
\hline Income (lower than three minimum wage) $(\mathrm{n}=18)$ & $11 \%$ & $67 \%$ & $22 \%$ \\
\hline Income (above twelve minimum wage) $(\mathrm{n}=11)$ & $18 \%$ & $64 \%$ & $18 \%$ \\
\hline
\end{tabular}

Source: Authors

\section{Classical variables about Meaning of Work}

The main classical variables about the meaning of work (MOW International Research Team, 1987) are: (i) absolute and relative centrality, (ii) work role identification (iii) valued work outcomes and (iv) importance of work goals.

Work centrality (i) (Chart 3) reflects the importance work has in relation to life itself and its other aspects. The absolute centrality tries to answer to "how important and significant is work on someone 's life as a whole", on a range from 1 to 7 . The average was 5,7 with little difference between the subgroups. Subtle differences were perceived with respect to income, where people with low income tend to rate as higher, compared to those of high income.

Chart 3. Absolute centrality of work and the meaning of work

\begin{tabular}{cccc}
\hline Scale & Job $(\mathbf{n}=\mathbf{6})$ & Career $(\mathbf{n}=\mathbf{3 6})$ & Calling $(\mathbf{n}=\mathbf{1 7})$ \\
\hline 1 (lower) & $0,0 \%$ & $2,8 \%$ & $5,9 \%$ \\
\hline 2 & $16,7 \%$ & $0,0 \%$ & $0,0 \%$ \\
\hline 3 & $0,0 \%$ & $0,0 \%$ & $0,0 \%$ \\
\hline 4 (average) & $33,3 \%$ & $5,6 \%$ & $17,6 \%$ \\
\hline 5 & $0,0 \%$ & $19,4 \%$ & $5,9 \%$ \\
6 & $0,0 \%$ & $38,9 \%$ & $35,3 \%$ \\
\hline 7 (higher) & $50,0 \%$ & $33,3 \%$ & $35,3 \%$ \\
\hline
\end{tabular}

Source: Authors, based on MOW International Research Team (1987)

The relative centrality proposes an analysis of work comparing to other aspects of life: free time and leisure, community, religiosity and family. The overall result showed a high centrality of work (Chart 4) as the bigger one, but with a similar average.

Chart 4. Relative centrality of work and the meaning of work

\begin{tabular}{cccc}
\hline Relative work centrality & Job $(\mathbf{n}=\mathbf{6})$ & Career $(\mathbf{n}=\mathbf{3 6})$ & Calling $(\mathbf{n}=\mathbf{1 7})$ \\
\hline Leisure & 20,0 & 20,9 & 18,3 \\
\hline Community & 6,3 & 9,1 & 14,6 \\
\hline Work & 37,5 & 28,0 & 33,0 \\
\hline Religion & 15,0 & 10,7 & 11,6 \\
\hline Family & 21,3 & 31,3 & 23,9 \\
\hline
\end{tabular}

Source: Authors, based on MOW International Research Team (1987)

Work role identification (ii) tries to understand the priority among work aspects. The comparative analysis of the meaning of work had different results. The "job" group better valued the kind of occupation and profession, as well as money, comparing to the other 
groups. A relevant point for organizations is that for nearly all the subgroups, their organization is the last ranked in the (Chart 5).

Chart 5. Work role identification and the meaning of work

\begin{tabular}{cccc}
\hline Work role identification & Job $(\mathbf{n}=\mathbf{6})$ & Career $(\mathbf{n}=\mathbf{3 6})$ & Calling $(\mathbf{n}=\mathbf{1 7})$ \\
\hline The tasks I do while working & 2 & 1 & 1 \\
\hline The product or service I provide & 4 & 2 & 2 \\
\hline The type of occupation or profession I am in & 1 & 3 & 3 \\
\hline The type of people with whom I work & 5 & 5 & 4 \\
\hline The money I receive from my work & 3 & 4 & 5 \\
\hline My company or organization & 6 & 6 & 6 \\
\hline
\end{tabular}

Source: Authors, based on MOW International Research Team (1987)

Regarding valued work outcomes (iii), work as self-fulfilment was one of the major reasons, and the importance of work with other people was one of the least. Analysing the division about the meaning of work (Chart 6) it is evident the link between people who perceive work as job and money (as seen previously). Status and prestige were also of the little importance for this subgroup (almost three times less than for the private schools subgroup, for example). Curiously, work as a way to serve society had similar averages, and the most acceptable theoretical possibility would people be better aligned with the Calling group. Work as a way of personal fulfilment was coherent, most valued by those who see work as calling.

Chart 6. Valued work results and the meaning of work

\begin{tabular}{cccc}
\hline & Job (n=6) & $\begin{array}{c}\text { Career } \\
(\mathbf{n = 3 6})\end{array}$ & $\begin{array}{c}\text { Calling } \\
(\mathbf{n = 1 7})\end{array}$ \\
\hline Working gives you status and prestige & 4,2 & 11,7 & 8,6 \\
\hline Working provides you with an income that is needed & 35,0 & 24,6 & 25,0 \\
\hline Working permits you to have interesting contacts with other people & 18,3 & 17,5 & 14,9 \\
\hline Working is a useful way for you to serve society & 22,5 & 18,4 & 22,5 \\
\hline Working itself is basically interesting and satisfying to you & 20,0 & 27,8 & 30,0 \\
\hline
\end{tabular}

Source: Authors, based on MOW International Research Team (1987)

Regarding importance of work goals (iv), the majority defined interesting work as the most priority and "much variety" as less priority (Chart 7). Analysing the subgroups in relation to the meaning of work, the calling group prioritized self-sufficiency more than the average, according to Paula (1988), however, with low result concerning interpersonal relations.

Chart 7 - Importance of work goals and the meaning of work

\begin{tabular}{cccc}
\hline & Job (n=6) & $\begin{array}{c}\text { Career } \\
(\mathbf{n}=\mathbf{3 6})\end{array}$ & $\begin{array}{c}\text { Calling } \\
(\mathbf{n}=\mathbf{1 7})\end{array}$ \\
\hline INTERESTING work (work that you really like) & 2 & 1 & 1 \\
\hline A lot of opportunity to LEARN new things & 1 & 2 & 3 \\
\hline good INTERPERSONAL relations (co-workers) & 3 & 4 & 6 \\
\hline good PAY & 4 & 3 & 2 \\
\hline good opportunity for upgrading or PROMOTION & 8 & 5 & 9 \\
\hline $\begin{array}{c}\text { experience } \\
\text { CONVENIENT work hours }\end{array}$ & 5 & 6 & 7 \\
\hline
\end{tabular}




\begin{tabular}{cccc}
\hline $\begin{array}{c}\text { good physical working CONDITIONS (such as light, temperature, } \\
\text { cleanliness, low noise level) }\end{array}$ & 6 & 8 & 8 \\
\hline good job SECURITY & 9 & 9 & 10 \\
\hline a lot of AUTONOMY (you decide how to do your work) & 11 & 10 & 4 \\
\hline a lot of VARIETY & 10 & 11 & 11 \\
\hline
\end{tabular}

Source: Authors, based on MOW International Research Team (1987)

\section{Expectations of the ideal work environment}

With the purpose of explaining the relation between the meaning of work and its motivations and expectations, an open question was asked: "imagine the ideal company or ideal working environment. What does it look like? Describe up to three characteristics or behaviours that defines such work environment". The following chart is a summary of the first results, divided by the three meaning of work subgroups.

Chart 8. Summary of work expectations and meaning of work

\begin{tabular}{cc}
\hline $\begin{array}{c}\text { Meaning of } \\
\text { Work Group }\end{array}$ & Work expectations \\
\hline Job & $\begin{array}{c}\text { Most of the responses are related to aspects previously verified, particularly with } \\
\text { respect to salary. Other results were the growth and interpersonal relationship. }\end{array}$ \\
\hline Career & $\begin{array}{r}\text { None of the answers pointed salary as a key-factor for the ideal company. Many } \\
\text { aspects concerning work coordination and interpersonal aspects came up. }\end{array}$ \\
\hline Calling & $\begin{array}{r}\text { People who see work as calling gave answers more focused on values ("justice, } \\
\text { respect, freedom"), commitment, flexibility and an ideal. }\end{array}$ \\
\hline
\end{tabular}

Source: Authors

Therefore, qualitative open answers were simple, but powerful and consistent. People who see work as a job values material needs and career aspects. People who perceive work as career consider as ideal topics related to environment, team and learning. On the other hand, people who sees work as calling take more into consideration as ideal aspects more related to inner motivation and personal values.

\section{Awareness and perceived relevance}

In order to reveal the importance of the theme to the participants, it was asked how new the theme was for them: "How much thinking about this subject is new for you?". It was confirmed the relevance of the theme, with more than $70 \%$ of grand total considering it as an obvious subject, already discussed on daily basis (results between 4 and 5) (Chart 9). Comparing the meaning of work to subgroups, the results of people who understand work as job showed the least relevance, but even so, high.

Chart 9. Awareness of the theme and the meaning of work subgroups

\begin{tabular}{cccc}
\hline & Job $(\mathbf{n = 6})$ & Career $(\mathbf{n = 3 6 )}$ & Calling (n=17) \\
\hline 1 (never thought) & $0 \%$ & $3 \%$ & $0 \%$ \\
\hline 2 & $17 \%$ & $11 \%$ & $6 \%$ \\
\hline 3 & $17 \%$ & $14 \%$ & $13 \%$ \\
\hline 4 & $33 \%$ & $31 \%$ & $50 \%$ \\
\hline 5 (think it is obvious) & $33 \%$ & $42 \%$ & $31 \%$ \\
\hline
\end{tabular}


Source: Authors

Along the same theme of relevance and awareness, it was asked: "How much do you believe that thinking more about this subject could be useful in your life?". It was shown an expressive result, with 90\% of the general answers between 4 and 5, in a scale from 1 to 5 (Chart 10), confirming that it is a valuable and relevant theme. Among the oldest, there were a bigger percentage of responses between 1 and 3 (30\%), what can be interpreted as some belief about age.

Chart 10. Perceived relevance of the theme and the meaning of work

\begin{tabular}{cccc}
\hline & Job $(\mathbf{n = 6})$ & Career $(\mathbf{n = 3 6 )}$ & Calling (n=17) \\
\hline 1 (lower) & $0 \%$ & $0 \%$ & $6 \%$ \\
\hline 2 & $17 \%$ & $0 \%$ & $6 \%$ \\
\hline 3 & $17 \%$ & $6 \%$ & $6 \%$ \\
\hline 4 & $17 \%$ & $17 \%$ & $12 \%$ \\
\hline
\end{tabular}

Source: Authors

One last data gathered analyses commitment on the theme. It was asked the willingness of the person to a new thirty-minute personal meeting about the subject. Generally, $46 \%$ were interested in talking more. Regarding this question and the meaning of work, people who see work as job showed less availability to discuss about the theme, presenting less engagement (Chart 11).

Chart 11. Willingness in deepening the interview

\begin{tabular}{cccc}
\hline & Job $(\mathbf{n}=\mathbf{6})$ & Career $(\mathbf{n}=\mathbf{3 6})$ & Calling $(\mathbf{n = 1 7})$ \\
\hline No & $67 \%$ & $53 \%$ & $56 \%$ \\
\hline Yes & $33 \%$ & $47 \%$ & $44 \%$ \\
\hline
\end{tabular}

Source: Authors

\section{CONCLUSION}

This work presents four major conclusions: (i) It has been demonstrated that it is possible to analyze work as a job, a career or a calling; (ii) most respondents (90\%) sees work as more than just a job; (iii) It was shown that each subgroup has different drivers, consistently with the literature; (iv) It was also demonstrated that the theme is perceived as being of great relevance for young people.

\section{Job, career or calling: a coherent approach}

The first conclusion was to identify that it was possible to describe the meaning of work as a Job, Career or Vocation, according to the Work-Life Questionnaire (Wrzesniewski et al., 1997). Internal consistency in the responses was found, and the use combined with the classic field questionnaire proposed by the MOW International Research Team (1987) was considered coherent. The results (Chart 1) showed relative consistency, compared to the reference work (Wrzesniewski et al., 1997), being possible to clearly identify the three subgroups. The standard deviation was greater than the reference study, perhaps because the sample was smaller.

\section{More than just a job}

The second main conclusion was that most respondents do not see work as just a job. Only $10 \%$ classified the view of work as a job, and $90 \%$ were divided between career (61\%) and calling (29\%). 
It was perceived some difference from the literature regarding the percentage between the three subgroups. Wrzesniewski et al. (1997) identified an egalitarian pattern in percentage, that is, approximately $33 \%$ of the total of people found themselves in one of the categories, and this pattern was repeated even when making a subdivision of analysis. For this research, the results were significantly different (most $61 \%$ as a career, calling followed by $29 \%$ and job $10 \%$ ). The biggest difference is in a smaller number of people who see work as a job and a larger number as a career. According to Wrzesniewski et al. (1997), a higher percentage of people as a career may be due to age and, consequently, to the desire to grow in life and career early in life. As the respondents were mostly between 18 and 27 years old, this result was confirmed. Two other hypotheses can be raised. The first related to the topicality of the theme, since more than 20 years have passed since the study carried out in 1997. With the dissemination of information online and increasingly the relevance discussed in society, it is possible that the vision of work as a job has lost space between the meanings attributed to work. The second hypothesis, which does not exclude the first, concerns the analyzed sample, being students of architecture and urbanism, a creative area, where naturally people look for career-oriented aspects (starting a business and winning prizes) and vocation (architecture as a way of serving society). Another pattern verified and related to Wrzesniewski et al. (1997) was that the instances of job and vocation are inversely proportional. For people more aligned with work as a job, the vision of work as a calling was the last of its ranking and the opposite happened with people who see work as a vocation. Wrzesniewski et al. (1997) found the same patterns.

\section{Different work motivators and expectations}

The third main conclusion was that each subgroup has a pattern of expectations in relation to the professional environment. People who faces work as a job indicated a strong link between work as a job and material benefits. It was the only subgroup that mentioned the issue of salary as the main issue.

Regarding people who faces work as a career, none of the answers put salary as a key factor for the ideal company. Many aspects have emerged in relation to work coordination and interpersonal aspects. This corroborates and divides this subgroup and the group that sees work as a job, as it was not seen material expectations in relation to work environment.

Regarding those who faces work as a calling, people related their aspirations and desires to intrinsic aspects, such as values-oriented actions ("justice, respect, freedom"), engagement, flexibility and an ideal of life. This contrasts with the view of work as a job, where the issue of salary and material benefits was mainly perceived. It also demonstrated the importance of personal fulfillment, the balanced work centrality and greater community involvement.

The qualitative questions, added to the other results, corroborated the view of the correlation of intrinsic motivation with work as a vocation and extrinsic with work as a job (Rijavec et al., 2016).

This theme connects practical issues for companies such as hiring and motivating employees. Understanding that the meaning of work is an influential variable can help recruiters to search for candidates and also leaders to get to know their teams better to get better results.

\section{A relevant theme for young students}

The fourth conclusion, and one of the most expressive, relates to the perceived relevance on the topic. The vast majority of people identified the topic as relevant to be discussed. In addition to this, the topic already seems to be something discussed and part of people's daily lives, and almost half of the people made themselves available to talk more about the subject, which is something significant, considering the busy life in which they are going through.

With these data it is clear that (i) the theme is something that is already circulating among students (for many it is an obvious subject, it is not new); (2) reflecting on the theme is considered extremely relevant by students. This result shows that it is important and relevant for young students to explore issues about the meaning of work and it is suggested that 
universities and companies may increasingly address these issues with students and employees.

Therefore, this paper demonstrated that it is possible to analyze work as a job, a career or a calling and the methodology used is consistent for the Brazilian context. It was possible to describe that most people see work as something more than just a job and it's material aspects, with a large part seeing it as a career, followed by calling and finally as a job. It was demonstrated that each subgroup has different motivators and expectations in relation to the work environment and that meaning of work is extremely relevant for young university students, requiring further studies.

In order to proceed with this work, some limits were seen, as well as opportunities for further studies, such as: (i) sample size and qualitative analyses; (ii) Use of random answers as the possibility of improvement; (iii) update of terms and variables in questionnaires; (v) studies about the meaning of work and age as opportunity for future researches; (vi) the use of qualitative approach together with questionnaires as an opportunity to clarify some of the topics here pointed.

\section{REFERENCES}

Ardichvili, A. and Kuchinke, K.P. (2009), "International perspectives on the meanings of work and working: current research and theory", Advances in Developing Human Resources, Vol. 11, No. 2, http://dx.doi.org/10.1177/1523422309333494.

Bendassolli, P. (2009), Significado do Trabalho e Carreira Artística, Tese de Doutorado em Organização, Recursos Humanos e Planejamento, Escola de Administração de Empresas de São Paulo, Fundação Getulio Vargas, São Paulo.

Bendassolli, P.F. and Borges-Andrade, J.E. (2011), "Significado do trabalho nas indústrias criativas", Revista de Administração de Empresas, Vol. 51, No. 2, pp. 143-159. http://dx.doi.org/10.1590/s003475902011000200003.

Bendassolli, P.F. and Borges-Andrade, J.E. (2015), "Meaning, meaningfulness, and tensions in artistic work", Revista Psicologia Organizações e Trabalho, Vol. 15, No. 1, pp. 71-81. http://dx.doi.org/10.17652/rpot/2015.1.305.

Bendassolli, P.F., Coelho-Lima, F., Pinheiro, R.A. et al. (2015), "The Brazilian scientific production on sense and meaning of work: review of terminological use and current thematic classifications", Avances en Psicología Latinoamericana, Vol. 33, No. 2, pp. 203-221. http://dx.doi.org/10.12804/apl33.02.2015.03.

Berg, J.M., Wrzesniewski, A. and Dutton, J.E. (2010), "Perceiving and responding to challenges in job crafting at different ranks: When proactivity requires adaptivity", Journal of Organizational Behavior. http://dx.doi.org/10.1002/job.645.

Borges, L.O., (1997), “Os atributos do significado do trabalho”, Psicologia: Teoria e Pesquisa, Vol. 13, p. 211 220.

Brief, A. P. and Nord, W. R., (1990), "Meanings of Occupational Work: A Collection of Essays", Lexington Books, USA.

Brief, A.P., Konovsky, M.A., Goodwin, R. et al. (1995), "Inferring the meaning of work from the effects of unemployment", Journal of Applied Social Psychology, Vol. 25, No. 8, pp. 693-711. http://dx.doi.org/10.1111/j.1559-1816.1995.tb01769.x.

Bunderson, J.S. and Thompson, J.A. (2009), "The call of the wild: zookeepers, callings, and the doubleedged sword of deeply meaningful work", Administrative Science Quarterly. http://dx.doi.org/10.1002/9781118785317.weom020145.

Dik, B.J. and Duffy, R.D. (2009), "Calling and vocation at work: definitions and prospects for research and practice", The Counseling Psychologist, Vol. 37, No. 3, pp. 424-50. http://dx.doi.org/10.1177/0011000008316430.

Drenth, P.J.D. (1991), "Work meanings: a conceptual, semantic and developmental approach", European Work and Organizational Psychologist, Vol. 125-133, pp. 125-133. http://dx.doi.org/10.1080/09602009108408517.

Elangovan, A.R., Pinder, C.C. and McLean, M. (2010), "Callings and organizational behavior", Journal of Vocational Behavior. http://dx.doi.org/10.1016/j.jvb.2009.10.009.

Fox, A. (1980), The Meaning of Work. The Politics of Work and Organizations, Open University Press, Milton Keyes. 
Geldenhuys, M., Łaba, K. and Venter, C.M. (2014), "Meaningful work, work engagement and organisational commitment", SA Journal of Industrial Psychology, Vol. 40, No. 1. http://dx.doi.org/10.4102/sajip.v40i1.1098.

Goulart, P.M. (2009), "O significado do trabalho: delimitações teóricas (1955-2006)", Cadernos de Psicologia Social do Trabalho, Vol. 12, No. 1, pp. 45-55. http://dx.doi.org/10.11606/issn.1981-0490.v12i1 p47-55.

Gratton, L. (2010), "Forces shaping the future of work", Business Strategy Review, Vol. 21, No. 3, pp. 16-23.

Grillo, P.M. (2019), Emprego, carreira ou vocação: o significado do trabalho e a formação universitária para estudantes de arquitetura e urbanismo em Niterói-RJ, Dissertação de Mestrado em Engenharia de Produção, Universidade Federal do Rio de Janeiro, Instituto Alberto Luiz Coimbra de Pósgraduação e Pesquisa de Engenharia, Rio de Janeiro.

Hackman, J.R. and Oldham, G.R. (1980), Work Redesign, FT Press, Reading, Mass, USA, 1980, 330 p.

Hult, C. (2005), "Organizational commitment and person-environment fit in six western countries", Organization Studies. http://dx.doi.org/10.1177/0170840605049800.

Instituto Nacional de Estudos e Pesquisas Educacionais Anísio Teixeira - INEP, Software Inep Data. 2019, available at: https://inepdata.inep.gov.br/analytics/saw.dll?Dashboard (accessed 20 January 2019).

Kahn, W. A. (2007), "Meaningful connections: positive relationships and attachments at work", in Dutton, J.E. and Ragins, B.R. (Eds.), Exploring Positive Relationships at Work: Building a Theoretical and Research Foundation, Lawrence Erlbaum Associates Publishers, Nova Jersey, USA. LEA's organization and management series.

King, L.A. and Napa, C.K. (1998), "What makes a life good", Journal of Personality and Social Psychology, Vol. 75, No. 1, pp. 156-165. http://dx.doi.org/10.1037/0022-3514.75.1.156.

Lancaster, L.C. and Stillman, D. (2011), “The 'M Factor - How the Millennial Generation is Rocking the Workpkace”', NHRD Network Journal, Vol. 4, No. 4. http://dx.doi.org/10.1177/0974173920110428.

Lips-Wiersma, M. and Morris, L. (2009), "Discriminating between 'meaningful work' and the 'management of meaning"', Journal of Business Ethics, Vol. 88, No. 3, pp. 491-511. http://dx.doi.org/10.1007/s10551009-0118-9.

Locke, E.A. and Taylor, M.S. (1991), "Stress, coping, and the meaning of work", Columbia University Press, New York, $140 \mathrm{p}$.

May, D.R., Gilson, R.L. and Harter, L.M. (2004), "The psychological conditions of meaningfulness, safety and availability and the engagement of the human spirit at work", Journal of Occupational and Organizational Psychology, Vol. 77, No. 1, pp. 11-37. http://dx.doi.org/10.1348/096317904322915892.

Morin, E. M. (1996). “L'efficacité organisationnelle et sens du travail”, in Pauchaunt, T. (Ed.), La Quête du Sens: Gerer nos Organizations Pour la Snaté des Personnes, de nos Sociètés et de la Nature,Editions de l'organisation, Quebec, Canadá, pp. 257-286.

Morin, E. M., (1997), "Le sens du travail pour des gestionnaires francophones", Revue Psychologie du Travail e des Organizations, Vol. 3, No. 2, pp. 26-45.

Morin, E., Tonelli, M.J. and Pliopas, A.L.V. (2007), "O trabalho e seus sentidos", Psicologia e Sociedade. http://dx.doi.org/10.1590/s0102-71822007000400008.

Morse, N.C. and Weiss, R.S. (1955), "The function and meaning of work and the job", American Sociological Review, Vol. 20, No. 2, pp. 191-198. http://dx.doi.org/10.2307/2088325.

MOW International Research Team. (1987), The Meaning of Working, Academic Press, London, UK.

Paula Leite, C.B.L. (1998), Desenvolvimento de Carreira e Significado do Trabalho, Tese de Doutorado em Organização, Recursos Humanos e Planejamento, Fundação Getulio Vargas, São Paulo, SP.

Pratt, M.G., Ashforth, B.E., Cameron, K. et al. (2003), "Fostering meaningfulness in working and at work", in Cameron, K.S., Dutton, J.E. and Quinn, R.E. (Eds.), Positive Organizational Scholarship: Foundations of a New Discipline, Berrett-Koehler Publishers, San Francisco, pp. 309-327, available at: https://www.researchgate.net/publication/303052224_Fostering_meaningfulness_in_working_and_a t_work (accessed 24 July 2018).

Pratt, M.G., Rockmann, K.W. and Kaufmann, J.B. (2006), "Constructing professional identity: the role of work and identity learning cycles in the customization of identity among medical residents", Academy of Management Journal. http://dx.doi.org/10.5465/AMJ.2006.20786060.

Pryor, R.G.L. and Davies, R. (1989), "A comparison of conceptualizations of work centrality", Journal of Organizational Behavior, Vol. 10, No. 3, pp. 283-9. http://dx.doi.org/10.1002/job.4030100308. 
Quintanilla, S.A.R. (1991), "The practical and theoretical importance of work meanings", European Work and Organizational Psychologist, Vol. 1, pp. 81-9.

Rijavec, M., Pečjak, S., Jurčec, L. et al. (2016), "Money and career or calling? Intrinsic vs. extrinsic work orientations and job satisfaction of Croatian and Slovenian teachers", Croatian Journal of Education, Vol. 18, No. 1, https://doi.org/10.15516/cje.v18i1.1163.

Roberson, L. (1990), "Functions of work meanings in organizations: work meanings and work motivation.", in Brief, A.P. and Nord, W.R. (Eds.), Issues in Organization and Management Series. Meanings of Occupational Work: A Collection of Essays, Lexington Books, Lexington, pp. 107-134, available at: https://psycnet.apa.org/record/1990-98937-004 (accessed 24 July 2018).

Rosso, B.D., Dekas, K.H. and Wrzesniewski, A. (2010), “On the meaning of work: a theoretical integration and review", in Brief, A.P. and Staw, B.M. (Eds.), Research in Organizational Behavior, pp. 91-127. http://dx.doi.org/10.1016/j.riob.2010.09.001.

Ruiz-Quintanilla, S.A. and England, G.W. (1996), "How working is defined: structure and stability", Journal of Organizational Behavior Management, Vol. 17, No. S1, https://doi.org/10.1002/(SICI)10991379(199612)17:1+<515::AID-JOB821>3.0.CO;2-G.

Schaufeli, W.B. and Bakker, A.B. (2004), "Job demands, job resources, and their relationship with burnout and engagement: a multi-sample study", Journal of Organizational Behavior, Vol. 25, pp. 293-315. http://dx.doi.org/10.1002/job.248.

Silva, É.R. and Proença Júnior, D. (2013), Revisão Sistemática da Literatura em Engenharia de Produção, Universidade Federal do Rio de Janeiro, Rio de Janeiro .

Spreitzer, G.M. (1996), "Social structural characteristics of psychological empowerment", Academy of Management Journal, Vol. 39, No. 2, pp. 483-504, http://dx.doi.org/10.2307/256789.

Weiss, R. and Kahn, R. L. (1961), "Definitions of work and occupation." Social Problems, Vol. 8, No 8, pp. 142-151.

Wrzesniewski, A. (2003), "Finding positive meaning in work”, in Cameron, K.S., Dutton, J.E. and Quinn, R.E. (Eds.), Positive Organizational Scholarship: Foundations of a New Discipline, Berrett-Koehler Publishers, San Francisco, pp. 296-308.

Wrzesniewski, A. and Dutton, J.E. (2001), "Crafting a job: revisioning employees as active crafters of their work", Academy of Management Review, Vol. 26, No. 2, pp. http://dx.doi.org/10.5465/AMR.2001.4378011.

Wrzesniewski, A., McCauley, C., Rozin, P., et al. (1997), "Jobs, careers, and callings: people's relations to their work", Journal of Research in Personality, Vol. 31, No. 1, pp. 21-33. http://dx.doi.org/10.1006/jrpe.1997.2162.

Author contributions: All the authors contributed equally to this paper. 